\title{
Pembinaan Ilmu Tajwid terhadap Anak-Anak di Masjid An-Nuur Kebun Raya OI
}

\author{
Abdul Gafur*1, Nurhasan², Endang Switri³ ${ }^{3}$ Apriyanti ${ }^{4}$ \\ 1,4Pendidikan Bahasa Sastra Indonesia, Fakultas Keguruan dan Ilmu Pendidikan, Universitas Sriwijaya, \\ Indonesia \\ 2,3Pendidikan Bahasa Sastra Inggris, Fakultas Keguruan dan Ilmu Pendidikan, Universitas Sriwijaya, \\ Indonesia \\ *e-mail: abdulgafur@unsri.ac.id ${ }^{1}$, nurhasan@unsri.ac.id ${ }^{2}$, endangswitri@unsri.ac.id ${ }^{3}$, \\ nurbuana@unsri.ac.id ${ }^{4}$
}

\begin{abstract}
Abstrak
Salah satu Tri Dharma Perguruan Tinggi yakni kegiatan pengabdian kepada masyarakat. Kegiatan yang dilakukan adalah pembinaan tentang baca Al-Qur'an dengan hukum bacaan nun mati atau tanwin ketika bertemu dengan huruf hijaiyah. Hal ini dilakukan karena banyaknya anggota masyarakat terutama anak anak yang belum memahami bahkan belum tau tentang hukum bacaan tajwid seperti ketika ada nun mati atau tanwin bertemu dengan huruf hijaiyah. Kegiatan merupakan kegiatan lanjutan dari kegiatan sebelumnya yakni mengajarkan membaca Al-Qur'an namun sebatas membaca dan untuk lanjutannya yakni hukum bacaan tajwid karena hal ini sangat penting dilakukan. Karena belajar dan mengajarkan Al-Qur'an merupakan kewajiban bagi kaum muslimin dan muslimat, dan ketika kita membaca Al-Qur'an dengan salah maka akan berdosa. Oleh karena itu kegiatan ini sangat perlu dilakukan. Tujuan kegiatan ini adalah untuk memberikan informasi pengetahuan kepada masyarakat khususnya bagi anak-anak yang di Kebun Raya kelurahan Indralaya Raya kecamatan Indralaya Kabupaten Ogan Ilir bagaimana cara membaca Al-Qur'an dengan baik dan benar menurut ilmu Tajwid terutama hukum bacaan nun mati atau tanwin bertemu dengan huruf hijaiyah, baik bacaan izhar halqi, ikhfa hakiki, iqlab, dan idghom bila ghunnah serta idghom ma'al ghunah. Karena ketika kita salah membaca huruf Al-Qur'an maka akan berpengaruh kepada makna atau arti dari ayat tersebut. Metode yang digunakan dengan ceramah, praktek dan simulasi mencari contoh yang ada dalam Al-Qur'an. Hasil dari kegiatan ini sangat bermanfaat khususnya kepada mereka yang belum sama sekali pernah belajar membaca Al-Qur'an menurut hukum bacaan ilmu tajwid serta bagi mereka yang pernah belajar untuk mengingatkan kembali pelajaran mereka. Hal ini bisa dilihat dari nilai rata rata sebelum kegiatan yakni 5 dan rata rata nilai sesudah kegiatan 7. Dan kegiatan ini perlu tindak lanjutan mengingat begitu pentingnya belajar al-qur'an beserta tajwidnya.
\end{abstract}

Kata Kunci: Al-Qur'an, Hukum Nun Mati atau Tanwin, Ilmu Tajwid

\begin{abstract}
One of the Tri Dharma of Higher Education is community service activities. The activities carried out are coaching about reading the Qur'an with the law of reading nun dead or tanwin when meeting with hijaiyah letters. This is done because many members of the community, especially children, do not understand or even know about the law of recitation of tajwid, such as when nun matai or tanwin meet hijaiyah letters. This activity is a continuation of the previous activity, which is teaching reading the Qur'an, but it is limited to reading and for the continuation, namely the law of recitation of recitation because this is very important to do. Because learning and teaching the Qur'an is an obligation for Muslims and Muslimat, and when we read the Qur'an incorrectly it will be a sin. Therefore, this activity is very necessary to do. The purpose of this activity is to provide information and knowledge to the community, especially for children who are in Kebun Raya, Indralaya Raya sub-district, Indralaya district, Ogan Ilir Regency, how to read the Qur'an properly and correctly according to Tajwid science, especially the law of reading nun dead or tanwin meets. with hijaiyah letters, both reading izhar halqi, ikhfa essential, iqlab, and idghom if ghunnah and idghom ma'al ghunah. Because when we misread the letters of the Qur'an it will affect the meaning or meaning of the verse. The method used is lectures, practice and simulations looking for examples in the Qur'an. The results of this activity are very useful especially for those who have never learned to read the Qur'an according to the law of reading the science of recitation and for those who have learned to remind them of their lessons. This can be seen from the average score before the activity which is 5 and the average score after the activity is 7. And this activity needs follow-up considering the importance of learning the Qur'an and its recitation.
\end{abstract}

Keywords: Al-Qur'an, Nun Mati or Tanwin Law, Tajweed Science. 


\section{PENDAHULUAN}

Menurut Manna' al Qaththan (2016; 34) menjelaskan bahwa Al-Qur'an merupakan kalam/perkataan Allah, diturunkan kepada Nabi Muhammad SAW dan ketika kita baca maka hal tersebut menjadi ibadah. Muhammad Ali al-Shabuni (2001: 3) berpendapat bahwa Al-Qur'an yaitu firman Allah bersifat mu'jizat yang didapat oleh Nabi Muhammad SAW melalui perantaraan Malaikat Jibril namun lafal dan artinya dari Allah SWT secara mutawatir dan bagi yang membacanya menjadi amal ibadah diawali surah Al Fatihah dan diakhiri surah An Nas.ada juga yang berpendapat bahwa Al-Qur'an (I. Musbikin. 2014: 341 merupakan perkataan Allah SWT yang bersifat mu'jizat diturunkan kepada nabi dan rasul yang terakhir melalui perantaraan Malaikat Jibril secara mutawatir, dan apabila kita baca, maka terhitung nilai ibadah dan tidak ditolak kebenarannya. Al-Qur'an diturunkan Allah SWT kepada Nabi Muhammad SAW sebagai petunjuk, pedoman, dan pelajaran bagi umat Islam (R. S. Nawawi. 2011: 239-240).

Hal ini sesuai dengan apa yang telah difirmankan Allah SWT.

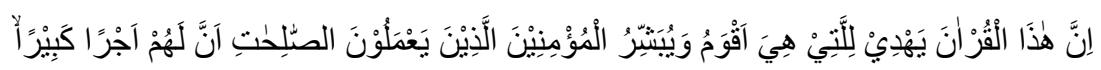

"Sesungguhnya Al-Qur'an ini memberikan petunjuk ke jalan yang lebih lurus dan memberi kabar gembira kepada orang-orang mukmin yang mengerjakan amal saleh sesungguhnya bagi mereka diberi ganjaran pahala yang amat besar" (Al-Isra': 9).

Al-Qur'an diturunkan untuk menjadi pegangan bagi umat manusia yang ingin mencapai kebahagiaan, baik di dunia maupun di akhirat. Al-Qur'an mengandung nilai-nilai yang berhubungan dengan keimanan, syariah, akhlak serta peraturan-peraturan yang mengatur tingkah laku dan tata cara hidup manusia. Al-Qur'an dengan susunan kata yang indah, kalimat yang baik dan terang serta gaya bahasa yang mengagumkan, memberikan inspirasi yang tidak pernah kering. Semakin kita dalami kitab suci ini, kita akan semakin yakin akan kebenaran firman Allah SWT.

Al-Qur'an merupakan petunjuk manusia dan rahmat untuk alam semesta ini. Di samping membedakan mana yang hak dan yang batil, Al-Qur'an juga sebagai penjelas kepada segala sesuatu, akhlak, moralitas, dan etika-etika yang harus kita laksanakan dalam kehidupan mereka, yang didalamnya terkumpul wahyu Allah SWT ketika kita membaca, mempelajarinya akan mendapatkan ketenangan hidup dan semoga akan mendapatkan rahmat Allah SWT. Oleh karena itu, kewajiban orang yang beragama Islam harus bisa membaca Al-Qur'an karena ia sebagai kitab sucinya, terutama anak-anak sebagai generasi penerus selanjutnya, karena mempelajari Al-Qur'an merupakan kewajiban (M. Q. Shihab. 2009: 46). Salah satu cara untuk mempelajari AlQur'an yakni dengan membacanya yang baik dan benar sesuai ilmu tajwid (S. Saprina, Irfan 2020). Karena mempelajari Al-Qur'an sangat penting dimulai sejak usia dini, baik dalam sekolah atau diluar sekolah (R. Hakim. 2014: 128). Sehingga Allah SWT telah mewajibkan kepada umatnya untuk membaca sejak Nabi Muhammad SAW menerima wahyu yang pertama yakni "Iqra". Sehingga dengan demikitan kita sebagai umat Islam harus mampu menerapkan perintah tersebut yaitu membaca apapun akan ciptaan Allah SWT termasuk mampu membaca Kitab Allah Al-Qur'anul Karim (Sarikin, 2012: 75).

Al-Qur'an merupakan pedoman dan rahmat untuk alam semesta ini. Di samping membedakan mana yang hak dan yang batil, Al-Qur'an juga sebagai penjelas kepada segala sesuatu, akhlak, moralitas, dan etika-etika yang harus kita laksanakan dalam kehidupan mereka, yang didalamnya terkumpul wahyu Allah SWT ketika kita membaca, mempelajarinya akan mendapatkan ketenangan hidup dan semoga akan mendapatkan rahmat Allah SWT. Oleh karena itu, kewajiban orang yang beragama Islam harus bisa membaca Al-Qur'an karena ia sebagai kitab sucinya, terutama anak-anak sebagai generasi penerus selanjutnya, karena mempelajari Al-Qur'an merupakan kewajiban (M. Q. Shihab. 2009: 46). Salah satu cara untuk mempelajari AlQur'an yakni dengan membacanya. Karena mempelajari Al-Qur'an sangat penting dimulai sejak usia dini, baik dalam sekolah atau diluar sekolah (R. Hakim. 2014: 128). Sehingga Allah SWT telah mewajibkan kepada umatnya untuk membaca sejak Nabi Muhammad SAW menerima 
wahyu yang pertama yakni "Iqra". Sehingga dengan demikitan kita sebagai umat Islam harus mampu menerapkan perintah tersebut yaitu membaca apapun akan ciptaan Allah SWT termasuk mampu membaca Kitab Allah Al-Qur'anul Karim (Sarikin, 2012: 75). Selain membacanya sebagai pedoman hidup umat muslim ada beberapa sikap komimennya terhadap Al-Qur'an, yaitu: mengimani, mempelajari dan mengamalkan serta mendakwahkannya (Nurhasan, dkk, 2011: 85).

Namun, di era globalisasi sekarang ini, Al-Qur'an yang begitu indah bacaannya sudah dilupakan sebagian orang. Mereka lebih memilih bacaan buku-buku ilmu pengetahuan modern atau menonton televisi yang sarat dengan budaya hedoisme daripada membaca Al-Qur'an. Dan terkadang masih banyak yang membaca Al-Qur'an masih keliru akan hukum bacaan tajwidnya, seperti ketika membaca nun mati atau tanwin bertemu dengan huruf hijaiyah yang dua puluh delapan. Dengan ilmu tajwid maka kita akan mengetahui bagaimana cara membacanya dengan baik dan benar. Oleh sebab itu, umat muslim harus mempunyai pedoman dalam mempelajari AlQur'an sehingga akan terhindar dari kesalahan-kesalahan membaca Al-Qur'an yaitu Ilmu Tajwid. Salah satu bentuk dan upaya umat muslim untuk memuliakan kitab suci Al-Quran adalah dengan membacanya dan menghafalnya, namun tak kalah penting adalah memberikan bimbingan kepada anak-anak yang masih belum mengerti akan hukum bacaan tajwid ketika membaca AlQur'an itu sendiri.

Tajwid secara etimologi masdar dari kata jawwada (tahsin) membaguskan sesuatu (Ashadiqi, M. Hasbi dkk. 2020. V. Mustiawani, 2018. A. Rambe, Arfa, dkk. 2020: 107. M. J. Aqel, N. M. Zaitoun. 2015. A. Dani, 2000;68), dan secara istilah tajwid merupakan mengeluarkan hurufhuruf dari tempat keluarnya (mahrojnya) dengan memberi hak dan mustahaknya (A. Y. Kurnaedi, 2013: 39). Yang dimaksud dengan hak huruf adalah sifat asli yang selalu bersama dengan huruf tersebut, seperti al-jahr, isti'la, istifal, sedangkan mustahak huruf adalah sifat yang nampak sewaktu-waktu, seperti tafkhim, tarqiq, ikhfa. Secara garis besar ilmu tajwid adalah ilmu yang mengajarkan tentang bagaimana cara membaca Al Qur'an yang baik dan benar. Tujuan ilmu tajwid adalah memelihara bacaan Al Qur'an dari kesalahan dan perubahan serta memelihara lisan (mulut) dari kesalahan membaca (V. Maarif, dkk. 2018: 94).

Dari sumber yang di dapat di lapangan bahwa anak-anak yang berdomisili di Kebun Raya kelurahan Indralaya Raya tersebut sangat banyak karena dari data yang di peroleh sementara berjumlah lebih kurang 25 anak laki-laki dan perempuan yang berusia dari 3 tahun sampai dengan 16 tahun. Usia PAUD sampai SMA Dan mereka ini belajar baca tulis Al-Qur'an di luar kebun raya yang apabila ditempuh dengan jalan kaki cukup jauh tapi ada juga yang mengendarai sepeda dan diantar oleh orang tua mereka, seperti di Pondok Pesantren AlIttifaqiyah dan sebagainya.

Dari data yang diperoleh sudah pernah diadakan pengabdian masyarakat terhadap pengajian anak-anak (A. Gafur, dkk. 2017) dalam belajar Iqra dan Al-Qur'an tetapi mereka belum banyak mengenal hukum bacaan ketika membaca Al-Qur'an itu sendiri diantaranya ketika ada nun mati atau tanwin dan lain sebagainya. Karena ini merupakan kelanjutan dari kegiatan sebelumnya bimbingan bacaan Al-Qur'an saja namun belum bidang tajwid. Oleh karena itu, berangkat dari permasalahan yang muncul inilah akan diadakan kegiatan bimbingan dalam hal baca Al-Qur'an dengan menggunakan ilmu tajwid, khusus materi nun mati atau tanwin bertemu dengan huruf hijaiyah yang judul "Pembinaan Ilmu Tajwid terhadap Anak-Anak di Masjid AnNuur Kebun Raya OI".

\subsection{Identifikasi dan Perumusan Masalah}

Pembelajaran merupakan proses interaksi pendidik dengan peserta didik dan sumber belajar pada suatu lingkungan belajar (https://id.wikipedia.org/wiki/Pembelajaran). Pembelajaran yang dilaksanakan dengan secara baik dan tepat akan memberikan kontribusi yang sangat dominan bagi siswa, sebaliknya pembelajaran yang dilaksanakan dengan cara yang tidak baik akan menyebabkan potensi siswa sulit dikembangkan (Muchith, 2008: 1).

Begitu juga pembelajaran baca Al-Qur'an perlu dilakukan dengan pembelajaran dan kemampuan guru yang baik sehingga dapat memberikan kualitas yang baik pula. Salah satu 
metode yang digunakan adalah metode sorogan, yakni metode belajar secara individual (Individual Learning) dimana seorang pelajar berhadapan dengan seorang guru dan terjadi interaksi saling mengenal di antara keduanya. Jamaluddin dkk (2019: 125-126), mengatakan metode sorogan yaitu santri menyetorkan kitab (sorog) yang akan dibahas dan guru menyimak setelah itu beliau memberi komentar dan bimbingan yang dianggap perlu bagi santri. Metode ini sering digunakan dalam pembelajaran kitab kuning di lembaga pendidikan pondok pesantren. Di mana dalam metode ini seorang pengasuh akan dapat mengetahui langsung kelemahan muridnya dalam proses pembelajaran, begitu juga dalam pembelajaran bacaan tajwid Al-Qur'an. Sehingga di dalam pelaksanaan siswa akan dapat langsung dibimbing.

Hal inilah yang akan dilakukan terhadap anak-anak yang berdomisili di Kebun Raya Indralaya Raya. Karena banyaknya anak-anak yang sudah bisa baca Al-Qur'an namun ilmu tajwidnya masih kurang, mengingat SDM-nya ada dalam hal ini adanya dosen pendidikan agama islam dan di bantu oleh masyarakat dan pelajar pondok pesantren yang memiliki kemampuan dalam hal baca Al-Qur'an, khususnya ilmu tajwid. Dan juga kegiatan ini sangat membantu perekonomian masyarakat karena tidak dikenakan biaya apalagi di masa COVID-19, sehingga masyarakat sangat setuju akan diadakan kegiatan ini.

Dan program ini membantu pemerintah dalam hal pemberantasan buta aksara baca tulis Al-Qur'an begitu juga program dari pihak rektorat universitas sriwijaya, hal ini bisa dilihat sudah terbitnya buku yang sangat kecil namun sangat berharga untuk kita pelajari yakni buku Taisiriyah (2008) pada masa kepemimpinan rektor ibu Badia Perizade, namun tahap yang lebih tepat ketika mereka masih usia anak-anak sehingga untuk memudahkan mereka belajar bagaimana cara belajar membaca Al-Qur'an yang baik dan benar.

Adapun perumusan masalah dalam kegiatan pengabdian ini sebagai berikut:

1. Anak-anak belum mengerti dan memahami bagaimana hukum bacaan tajwid ketika ada nun mati atau tanwin bertemu dengan huruf hijaiyah.

2. Kurangnya pengetahuan tentang praktek hukum bacaan tajwid ketika ada nun mati atau tanwin bertemu dengan huruf hijaiyah.

\subsection{Kerangka Pemecahan Masalah}

Tabel 1. Kerangka Pemecahan Masalah

\begin{tabular}{|c|c|c|}
\hline Kondisi saat ini & Perlakuan yang diberikan & Kondisi yang diharapkan \\
\hline $\begin{array}{l}\text { Anak-anak belum mengerti dan } \\
\text { memahami bagaimana hukum } \\
\text { bacaan tajwid ketika ada nun } \\
\text { mati atau tanwin bertemu } \\
\text { dengan huruf hijaiyah. } \\
\text { Kurangnya pengetahuan } \\
\text { tentang praktek hukum bacaan } \\
\text { tajwid ketika ada nun mati atau } \\
\text { tanwin bertemu dengan huruf } \\
\text { hijaiyah. }\end{array}$ & $\begin{array}{l}\text { Dilakukan penjelasan mengenai } \\
\text { hukum bacaan tajwid ketika } \\
\text { ada nun mati atau tanwin } \\
\text { bertemu dengan huruf hijaiyah. } \\
\text { Dilaksanakannya pembinaan } \\
\text { dan pelatihan hukum bacaan } \\
\text { tajwid ketika ada nun mati atau } \\
\text { tanwin bertemu dengan huruf } \\
\text { hijaiyah. }\end{array}$ & $\begin{array}{l}\text { Dengan diberikannya } \\
\text { penjelasan mengenai hukum } \\
\text { bacaan tajwid ketika ada nun } \\
\text { mati atau tanwin bertemu } \\
\text { dengan huruf hijaiyah } \\
\text { Agar anak anak memiliki } \\
\text { kemampuan membaca hukum } \\
\text { bacaan tajwid ketika ada nun } \\
\text { mati atau tanwin bertemu } \\
\text { dengan huruf hijaiyah. }\end{array}$ \\
\hline
\end{tabular}

Adapun kerangka pemecahan masalah untuk menjawab perumusan masalah adalah mengadakan pembinaan dan pelatihan bagaimana hukum bacaan tajwid ketika ada nun mati atau tanwin bertemu dengan huruf hijaiyah di Masjid An-Nuur Kebun Raya kabupaten Ogan Ilir Sumatera Selatan.

\subsection{Tujuan dan Manfaat}

Pelaksanaan kegiatan pengabdian pada masyarakat yang dilaksanakan kepada anak anak pengajian di Masjid An-Nuur Kebun Raya Kecamatan Indralaya Kabupaten OI ini bertujuan untuk:

1. Memberikan pengetahuan, gambaran dan pemahaman yang jelas mengenai hukum bacaan tajwid ketika ada nun mati atau tanwin bertemu dengan huruf hijaiyah di pengajian anak anak Masjid An-Nuur Kebun Raya Kecamatan Indralaya Kabupaten Ogan Ilir. 
2. Memotivasi anak anak akan pentingnya mengetahui dan memahami serta mempraktekkan hukum bacaan tajwid ketika ada nun mati atau tanwin bertemu dengan huruf hijaiyah.

Berdasarkan tujuan di atas, maka manfaat dari pelaksanaan kegiatan ini anak anak di Masjid An-Nuur Kabupaten Ogan Ilir, sebagai berikut:

1. Dapat membantu anak-anak memperbaiki kualitas bacaan Al-Qur'an sesuai ilmu tajwid di bidang hukum bacaan ada nun mati atau tanwin bertemu dengan huruf hijaiyah.

2. Menimbulkan rasa percaya diri dan kemantapan anak anak pengajian di Masjid An-Nuur dalam hal hukum bacaan tajwid ketika ada nun mati atau tanwin bertemu dengan huruf hijaiyah.

\subsection{Tinjauan Pustaka/ Kajian Literatur}

Kitab suci Al-Qur'an secara etimologi berarti bacaan atau sesuatu yang dibaca. Mengandung arti bahwa menganjurkan kepada kita umatnya agar membaca Al-Qur'an, tidak hanya dijadikan sebagai hiasan rumah saja. Atau pengertian Al-Qur'an sama dengan menghimpun atau mengumpulkan. Yakni menghimpun beberapa huruf, kata dan kalimat satu dengan yang lain secara tertib sehingga tersusun rapi dan benar (M. Al-Qaththan, 1998: 15). Oleh karena itu, Al-Qur'an harus dibaca dan dipelajari dengan baik dan benar sesuai dengan makhraj, fashohah, dan sifat-sifat huruf, tajwid dan hukum-hukum yang melekat padanya.

Sedangkan secara terminologi, Al-Qur'an sebagaimana disepakati oleh para ulama dan ahli ushul fiqih adalah kalam Allah yang mengandung mu'jizat yang diturunkan kepada para Nabi dan Rasul melalui perantaraan malaikat Jibril yang tertulis pada mushaf yang diriwayatkan kepada kita secara Mutawatir, dinilai ketika membacanya, yang dimulai dari Surah Al-Fatihah dan diakhiri dengan An-Naas (Ash-Shabuni, 2001: 1-8, lihat juga Norani Abu, 2001: 1-4 dan A. M. Khon, 2008: 1-2).

Rasulullah bersabda dalam haditsnya yang berbunyi:

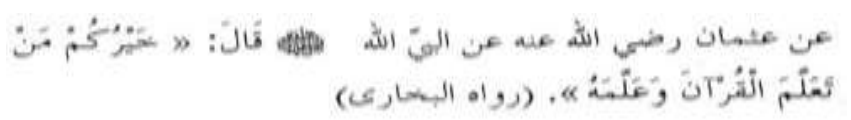

Dari Ustman bin Affan r.a berkata bahwa Rasulullah bersabda: "Sebaik-baik kamu adalah orang yang mempelajari Al-Qur'an dan mengajarkannya (H.R Bukhori).

Dari hadist tersebut jelas bahwa kita dituntut untuk mempelajari Al-Qur'an dan setelah itu mengajarkannya, namun sebelum mempelajarinya kita harus tahu bagaimana cara membacanya dengan baik dan benar, karena terkadang sudah baik bacaannya tetapi belum benar karena belum sesuai dengan makhraj hurufnya, fashohah dalam penyebutannya dan yang berkaitan dengan ilmu tajwid. Sehingga memang perlu untuk diperbaiki tentang bacaan tersebut dan kegiatan ini difokuskan kepada usia anak-anak mereka nanti tidak mengalami kendala lagi ketika mau membaca Al-Qur'an, khususnya di bidang ilmu tajwid.

Ilmu tajwid merupakan ilmu yang digunakan untuk mengetahui kaedah dan cara membaca huruf Al-Qur'an secara baik dan benar (H. Sayuti, t.t: 7. Mulia, Hadi, dkk. 2017, Sudiarjo, A., Mariana, A. R., \& Nurhidayat, W. 2015). Dan apabila huruf nun mati atau tanwin bertemu dengan huruf hijaiyah yang 28 ada 5 hukum bacaannya: 1) Izhar Halqi 2) Ihfa Hakiki 3) Iqlab 4) Idghom bila ghunnah dan 5) Idghom ma'alghunnah (Ibid: 9).

1. Izhar Halqi. Menurut bahasa, halqi artinya tenggorokan atau kerongkongan. Adapun arti izhar halqi secara istilah adalah mengeluarkan setiap huruf dari makhrajnya tanpa dengung (ghunnah) pada huruf yang diizharkan. Nun mati atau tanwin dibaca jelas bila bertemu dengan huruf halqi (tenggorokan). Ada enam huruf yang masuk kategori ini yaitu gho $(\dot{\varepsilon})$,

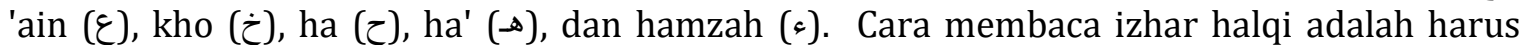
jelas dengan mengucapkan huruf nun sukun dan tanwin sesuai dengan makhraj dan sifat yang dimilikinya, kemudian diiringi dengan huruf izhar juga sesuai dengan makhraj dan sifat yang dimilikinya. Keenam huruf izhar halqi semua makhrajnya ada di tenggorokan sehingga 


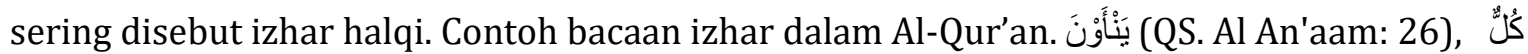

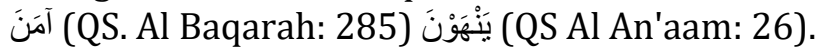

2. Ikhfa Hakiki. Ikhfa artinya menyamarkan. Nun mati atau tanwin dibaca ikhfa apabila

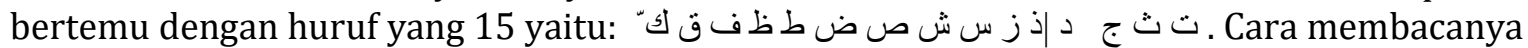
yaitu suara nun mati/tanwi masih tetap terdengar tetapi samar samar antara izhar dan idghom dan terus bersambung dengan makhraj huruf sesudahnya, sehingga kedengarannya seperti "ng" jika bertemu dengan ق ك ف dan adakalanya seperti "ng" dan "ny" jika bertemu dengan huruf ث ذ ز س ش ظف da nada kalanya seperti "ny" jika bertemu dengan dan ada

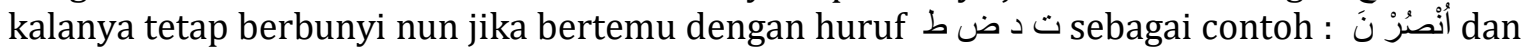
lain-lain.

3. Iqlab. Iqlab artinya menukar atau mengganti suatu huruf menjadi huruf yang lain berbeda dari huruf asalnya. Huruf nya ada satu yaitu ب. cara membacanya dengan mengganti huruf nun mati atau tanwin menjadi huruf mim mati disertai dengung. Contoh: مِنْ بَغْ بـ .

4. Idghom Bila Ghunnah. Artinya membunyikan nun mati atau tanwin dengan memasukkannya pada huruf sesudahnya dan dibaca tanpa mendengung. Hurufnya ada dua yakni $\lrcorner$ dan $J$. Misalnya: خَيْرُ لَكَ.

5. Idghom Ma'lghunnah. Artinya membunyikan nun mati atau tanwin dengan memasukkannya pada huruf sesudahnya dan dibaca dengan mendengung. Hurufnya ada 4 yakni: ي و م ن. Misalnya: مَنْ يَقُُْْْ .

Adapun kajian terdahulu tentang Al-Qur'an diantaranya yakni oleh Muhammad, Defi Habibi (2018). Tulisan menyatakan bahwa metode qiroati merupakan metode yang digunakan langsung mendengarkan dan praktek membaca Al-Qur'an sesuai Qaidah tajwid.

Syofria Nisda (2018). kegiatan pengabdian masyarakat dalam membantu santri dalam hal baca Al-Qur'an dan kegiatan ini berhasil hal ini dilihat dari hasil akhir kegiatan mayoritas nilai mereka tuntas semua.

Azmil Hashim A, Jahidih Saili, Mohd Aderi Che Noh (2015), dalam tulisannya menyatakan bahwa untuk mengidentifikasi hubungan antara guru (PCK) dengan prestasi belajar al-Quran siswa tajwid dalam Kelas Khusus Keterampilan Membaca dan Menghafal Al-Quran (KKQ) di Wilayah Persekutuan Kuala Lumpur. Hasil penelitian menunjukkan, terdapat hubungan signifikan yang lebih rendah antara PCK guru dengan prestasi belajar siswa tajwid Al-Qur'an di KKQ. Oleh karena itu, guru KKQ harus mengetahui pengetahuan ini karena merupakan salah satu faktor yang akan menentukan pembelajaran yang efektif selain itu akan mempengaruhi prestasi siswa dalam belajar tajwid.

Musbah J. Aqel, Nida M. Zaitoun (2015). Tulisan ini menjelaskan sebuah sistem pakar untuk kemampuan membaca Al-Qur'an suci dikembangkan untuk membantu Muslim non Arab untuk membaca Al-Qur'an sesuai dengan aturan Islam.

Bayan M. Alsharbi, Omar Mubin, Mauricio Novoa (2021). Tulisan ini menjelaskan bagaimana membangun simulator berdasarkan pembelajaran penguatan untuk meningkatkan pengalaman mengajar dalam pendidikan Al-Qur'an dan Islam untuk penutur bahasa Arab nonasli untuk mengevaluasi kekuatan dan kelemahan mereka dan memungkinkan sistem untuk membantu meningkatkan anak di satu sisi, dan memberikan laporan aktual yang akurat untuk setiap anak pada tangan yang lain.

Saprina, Sri. M.Irfan. (2020). Penelitian ini bertujuan untuk mengetahui kemampuan membaca Al-Quran, kemampuan memahami tajwid, dan hubungan antara kedua variabel tersebut pada mahasiswa Universitas Sriwijaya. Hasil penelitian ini menunjukkan bahwa sebagian besar mahasiswa baru Universitas Sriwijaya (42\%) memiliki kemampuan membaca pada rentang nilai 64-71 dan mayoritas penguasaan ilmu tajwid (36\%) pada rentang nilai 56-63.

Khairul, K., \& Haramain, M. (2018). Tujuan dari penelitian ini adalah untuk mendapatkan data empiris tentang kemampuan siswa dalam membaca Alquran sebelum dan sesudah diajarkan dengan menggunakan risalah digital ilmu tajwid dan untuk mendapatkan data empiris tentang kemampuan siswa dalam membaca Alquran sebelum dan sesudah menggunakan buku teks sebagai serta untuk mendapatkan informasi tentang perbedaan tingkat kemampuan membaca Alquran siswa pada kelas eksperimen dan kelas kontrol. Desain penelitian yang digunakan adalah nonequivalent control group design, artinya dalam desain ini kelas 
eksperimen maupun kelas kontrol tidak dipilih secara acak. Hasil penelitian adalah: (1) Tingkat kemampuan membaca Alquran siswa pada kelas eksperimen sebelumnya perlakuan tergolong dalam kategori buruk, namun setelah diberikan perlakuan berada pada kategori baik. (2) Tingkat kemampuan membaca Alquran siswa kelas kontrol sebelum diberikan perlakuan berada pada kategori kurang, namun setelah diberikan perlakuan berada pada kategori baik. (3) Terdapat perbedaan tingkat kemampuan membaca Alquran siswa kelas eksperimen dan kelas kontrol.

Habibbulloh, M., \& Arifin, A. (2019). Penelitian ini bertujuan menguji dan mengevaluasi efektivitas model pembelajaran kooperatif STAD berbantuan alat peraga Al-Qur'an terhadap peningkatan penguasaan tajwid hukum nun sukun dan tanwin siswa SD. Sampel diambil secara acak pada tingkatan kelas VI di salah satu Sekolah Dasar di Mojokerto sebanyak 20 siswa. Desain penelitian yang digunakan one group pretest posttest. Pengumpulan data dilakukan dengan uji kompetensi kemampuan membaca Al-Qur'an berisikan hukum nun sukun pada saat pretest dan posttest. Data analisis digunakan deskriptif kuantitatif, uji normalitas, Uji-t, dan N-gain. Temuan hasil penelitian diantaranya sampel penelitian berdistribusi normal, analisis uji-t didapatkan bahwa terdapat perbedaan yang signifikan antara hasil pretest dan posttest, serta N-gain menunjukkan bahwa peningkatan nilai posttest berkategori tinggi. Berdasarkan temuan penelitian disimpulkan bahwa model pembelajaran kooperatif STAD berbantuan alat peraga AlQur'an efektif meningkatkan penguasaan tajwid hukum nun sukun dan tanwin siswa SD.

Jariyah, A., \& Maya Reski Tasman, D. (2015). Dalam penelitian ini menggunakan penelitian Tindakan Kelas (classroomaction research) yang meliputi perencanaan tindakan berulang yaitu, perencanaan, pelaksanaan, observasi dan refleksi yang direncanakan dalam dua siklus. Data yang terkumpul dianalisis dengan menggunakan teknik analisis kuantitatif dan kualitatif. Untuk analisis kuantitatif digunakan statistik deskriptif yaitu rata-rata dan persentase, tabel frekuensi, persentase nilai terendah dan tertinggi. analisis kualitatif yang digunakan adalah kategorisasi skor skala 5. Media tajwid card ini dipilih karena merupakan kegiatan kolaboratif yang bisa digunakan untuk mengajarkan konsep, penggolongan sifat, fakta tentang suatu objek sehingga cara membaca Alquran santri sesuai dengan kaidah baca yang sebenarnya.

Semua kajian tersebut merupakan hasil dari penelitian yang sama tentang kajian al qur'an dan tajwid namun tulisan ini merupakan kegiatan pengabdian yang terjun langsung ke khalayak sasaran yang mengajarkan tentang hukum bacaan nun mati atau tanwin ketika bertemu dengan huruf hijaiyah.

\section{METODE}

Kegiatan ini berupa penyuluhan dan praktek yang disampaikan dengan metode ceramah, diskusi dan demonstrasi (praktik) bagaimana membaca Al-Qur'an dengan baik dan benar menurut ilmu tajwid.

Untuk melihat bagaimana kegiatan ini berhasil sesuai tujuan yang diharapkan dilakukan pre test terlebih dahulu untuk mengetahui kemampuan mereka tentang hukum nun mati atau tanwin bertemu dengan huruf hijaiyah sebelum diberikan bimbingan. Melihat hasil dari pre test anak anak masih banyak yang belum tahu akan ilmu tajwid terutama nun mati atau tanwin tersebut, hal ini beberapa ragam alasan melihat dari segi usia memang usia kelas $2-5$ sekolah dasar. Namun juga ada yang sudah mengetahui materi tersebut, hal ini ketika ditanya kepada anak tersebut sekolah di madrasah ibtidaiyah yang memang sudah mempelajari nya walau ketika praktek membacanya masih keliru.

Walaupun demikitan semua peserta diberikan materi yang sama dan penjelasan yang sama tidak dibeda bedakan satu dengan yang lainnya.

Adapun metode yang diberikan diantaranya; metode ceramah dan simulasi (prakatik) yakni menjelaskan materi terlebih dahulu dan langsung praktek dengan memberikan contoh dengan menggunakan Al-Qur'an. Dan meminta kepada mereka untuk mencari contoh yang ada dalam Al-Qur'an. Hal ini dilakukan supaya kegiatan ini lebih mudah dipahami oleh anak-anak. 
Materi yang diberikan selama proses kegiatan mulai dari Makhorijul Huruf, hukum nun mati atau tanwin di antaranya: Izhar halqi, Ikhfa hakiki, Iqlab, Idghom Bi Ghunnah dan Idghom Bila Ghunnah (lampiran 1).

Objek dari kegiatan ini adalah masyarakat yang tergabung dalam komunitas yang dikenal dengan nama Pengajian Anak-anak An-Nuur yang terletak di daerah kebun raya indralaya ogan ilir. Tingkat ketercapaian dari kegiatan ini diharapkan ketika di suruh baca AlQur'an harus baik dan benar baik dari segi makhorijul hurufnya dan ilmu tajwidnya khususnya hukum nun mati atau tanwin.

\section{HASIL DAN PEMBAHASAN}

Pengabdian ini dilaksanakan selama 4 malam karena waktunya setelah maghrib sampai jam 20.00 WIB, yakni pada tanggal 4 - 7 Oktober 2021, yang dihadiri oleh anak anak yang berdomisili di RT 07 kebun raya sebagai khalayak sasarannya. Yang berjumlah 23 orang terdiri dari laki laki 18 dan perempuan 5 orang yang hadir (Absensi Kehadiran).

Kegiatan berlangsung dari jam 18.00 WIB (maghrib berjamaah) sampai selesai. Kegiatan ini dilakukan pada malam hari karena menyesuaikan jadwal pengajian anak anak pada malam hari.

Diawali dengan pretest terlebih dahulu untuk mengetahui tingkat pemahaman peserta tentang tajwid hukum nun mati atau tanwin, maka dilanjutkan dengan memberikan materi hukum bacaan tajwid tentang nun mati atau tanwin bertemu dengan huruf hijaiyah di antaranya: hukum bacaan izhar halqi, ikhfa hakiki, iqlab, idghom bi Ghunnah dan idghom Ma'al ghunnah.

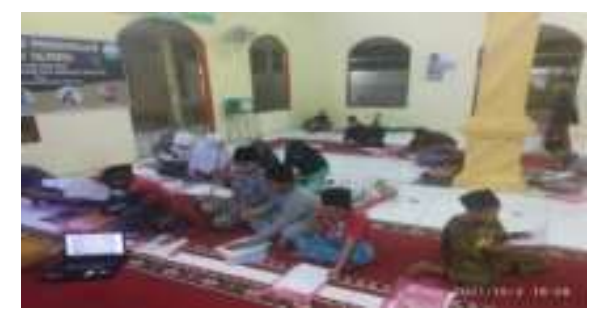

Gambar 1. Suasana Ketika Mengerjakan Soal

Selain materi tentang tajwid mereka diberikan ATK berupa pena, buku, map plastik dan materi tajwid serta uang transport sebagai penyemangat mereka walaupun tidak terlalu besar tapi bagi mereka sangat berarti. Dan juga berupa makanan ringan sehingga mereka sangat senang ikut kegiatan ini.

Setelah selesai memberikan penjelasan di pertemuan terakhir diberikan lagi soal berupa post test, dengan soal yang sama dengan pretest.

Adapun hasil dari kegiatan ini boleh dikatakan berhasil walaupun ini hanya dilihat dari hasil pre test dan post test anak anak. Walaupun demikitan ternyata masih adanya kendala dalam pelaksanaan kegiatan ini. Diantaranya; masih adanya peserta yang tidak serius mendengarkan materi, sehingga ketika ditanya mereka masih ada yang belum paham maka dilakukan lagi penjelasan ulang secara singkat. Masih ada juga yang lambat memahami materi hal ini disebabkan kemampuan mereka beda beda sesuai tingkatan usia mereka beda beda.

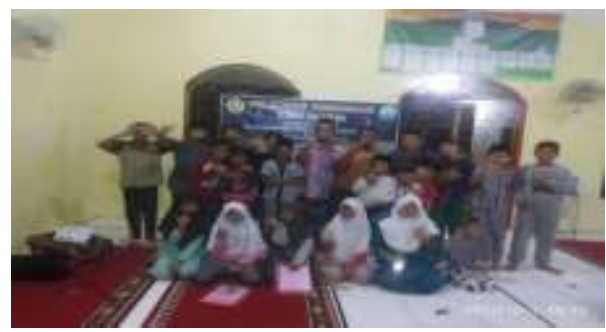

Gambar 2. Ketika Selesai Memberikan Materi 
Adapun nilai-nilai mereka dapat dilihat dari tabel berikut:

Tabel 2. Daftar Nilai Peserta Bimbingan Pengabdian Masyarakat

\begin{tabular}{clcc}
\hline NO. & \multicolumn{1}{c}{ NAMA } & PRE TEST & POST TEST \\
\hline 1 & Tsalis El Manika & 5 & 8 \\
2 & Harum Horiah & 5 & 7 \\
3 & Alisya Putri Oktariana & 4 & 7 \\
4 & Aji Gilang Satria & 5 & 8 \\
5 & M Arif Al Kahfi & 4 & 6 \\
6 & Yoga Pratama & 8 & 8 \\
7 & Harum & 4 & 6 \\
8 & Fiki & 3 & 6 \\
9 & M. Fadhil & 5 & 6 \\
10 & Marsya Fatiana & 4 & 6 \\
11 & Ainun Azka Albar & 4 & 5 \\
12 & Naisya Thazkiro & 5 & 8 \\
13 & A. Raihan & 6 & 8 \\
14 & Yuni Ardi & 4 & 7 \\
15 & Azri Varial Rizky & 8 & 6 \\
16 & Farhan & 2 & 7 \\
17 & Iyan & 9 & 7 \\
18 & Randi Bramstia & 9 & 10 \\
19 & M. Ilham Saputra & 7 & 6 \\
20 & Mario Setiawan & 6 & 8 \\
21 & Gali Purnama & 5 & 6 \\
22 & Kaffa Libya Albar & 3 & 8 \\
23 & M. Zaki & 6 & 7 \\
\hline & Jumlah & 121 & 161 \\
& Rata-rata & 5 & 10 \\
& Maksimal & 9 & 5 \\
\hline
\end{tabular}

Dari tabel di atas bisa kita perhatikan bahwasanya ada perbedaaan antara rata -rata nilai mereka sebelum dan sesudah kegiatan. Nilai rata pada pretest 5 dan posttest 7 . Ketika ditanya kepada anak yang nilainya baik pada pretest ternyata mereka sudah belajar di sekolah walaupun belum paham prakateknya dan mereka yang nilainya sangat kurang ternyata usia nya masih kelas 1 SD dan yang bersangkutan belum sama sekali belajar tajwid masih belajar iqro 2, sehingga belum bisa jawab soal yang diberikan sebelum kegiatan. Walaupun demikitan mereka semangat ikut kegiatan ini. Namun sangat tidak diharapkan ada dua anak yang nilai pretest nya lebih besar dari post test nya ketika ditanya ternyata mereka jawabannya kompak tergesa gesa sehingga salah jawab.

Dengan melihat hasil dari pretest dan post test maka dapat disimpulkan kegiatan ini berhasil dengan baik, harapannya mereka bisa menerapkan nya ketika baca Al-Qur'an dengan baik dan benar.

\section{KESIMPULAN}

Al-Qur'an merupakan perkataan Allah yang apabila kita baca menjadi nilai ibadah, namun ketika kita baca harus sesuai dengan ilmu tajwidnya karena ketika kita salah maka akan berdosa, tidak boleh sembarangan membaca Al-Qur'an yang hal ini Al-Qur'an beda dengan kitab yang lain. Diharapkan kegiatan ini berkelanjutan karena masih banyak materi tajwid tidak hanya tentang hukum nun mati atau tanwin, tapi mase banyak lagi yang lain seperti mim mati, alif lam dan sebagainya. 


\section{UCAPAN TERIMA KASIH}

Terima kasih kepada semua pihak yang telah menyukseskan kegiatan ini baik kepada institusi yakni kepada Unit Penelitian dan Pengabdian Masyarakat Fakultas Keguruan dan Ilmu Pendidikan Universitas Sriwijaya yang telah memberikan kontribusi berupa financial untuk kelancaran kegiatan ini.

Terima kasih juga kepada pengurus Masjid An-Nuur Kebun Raya Indralaya Raya yang telah memberikan izin, kesempatan waktu dan tempatnya untuk kegiatan ini, terutama kepada anak anak pengajian An-Nuur yang telah bersedia mengikuti kegiatan pengabdian ini dari awal sampai selesainya acara ini dan tak lupa pula kepada tim pengabdian dosen pendidikan agama islam universitas sriwijaya yang telah meluangkan waktunya sehingga terselenggaranya kegiatan ini mulai dari persiapan proposal sampai selesainya laporan kegiatan ini.

\section{DAFTAR PUSTAKA}

Abu Ya'la Kurnaedi. 2013. Tajwid Lengkap asy-Syafi'I. Jakarta: Pustaka Imam asy-Syafi'I.

Ad Dani. 2000. at Tahdid fil Itqan wa at Tajwid, Oman: Dar 'Ammar.

Alsharbi, Bayan, M, Omar Mubin, \& Mauricio Novoa. 'Quranic Education and Technology: Reinforcement Learning System for Non-Native Arabic Children', Procedia Computer Science 184 (2021), 307.

Anggriani Rambe, Arfa, dkk. 2020. Program Pengenalan Ilmu Tajwid Melaui Media Pembelajaran Pohon Ilmu. Maslahah Jurnal Pengabdian Masyarakat . Vol. 1, No. 2.105-115. Doi: 10.30596/maslahah.v\%vi\%i.59.

Ashadiqi, M. Hasbi dkk. 2020. Aplikasi Pembelajaran Ilmu Tajwid Berbasis Android. Jurnal $\begin{array}{lllllll}\text { Rekursif, } & \text { Vol. } & 8 & \text { No. } & 1 & \text { Maret 2020, ISSN 2303-0755 }\end{array}$ http://ejournal.unib.ac.id/index.php/rekursif/

Habibbulloh, M., \& Arifin, A. 2019. The Efektivitas Model Pembelajaran Kooperatif Stad Menggunakan Alat Peraga Alquran Untuk Meningkatkan Penguasaan Tajwid.Jurnal Pendidikan Agama Islam, 16(2), 189-202. https://doi.org/10.14421/ipai.2019.162-04.

Hashim, Azmil, dkk. The Relationship between Pedagogical Content Knowledge and al-Quran Tajweed Performance among Students KKQ in Malaysia. Procedia - Social and Behavioral Sciences 197 (2015) 1530 - 1537. 7th World Conference on Educational Sciences, (WCES2015), 05-07 February 2015, Novotel Athens Convention Center, Athens, Greece.

Jariyah, A., \& Maya Reski Tasman, D. 2015. Peningkatan Kemampuan Membaca Alquran Melalui Metode Tajwid Card Pada Santri Tk/Tpa Nurul Iman Jalan Rappokalling Kelurahan Tammua Kec. Tallo. Pena, 2(2), 329-338.

Khairul, K., \& Haramain, M. 2018. Aplikasi Digital Risalah Ilmu Tajwid dalam Meningkatkan Kemampuan Baca Alquran. KURIOSITAS: Media Komunikasi Sosial Dan Keagamaan, 11(2), 145-157. https://doi.org/10.35905/kur.v11i2.726

M. Quraish Shihab. 1998. Membumikan Al-Qur'an, Jakarta: PT. Mizan Pustaka.

M.A, S. nisda. 2018. A Pelatihan Baca Tulis Al-Quran Terhadap Santri Madrasah Diniyah Takmiliyah Awaliyah (Mdta) Amanah Di Jorong Simpang Ampek Nagari Lingkuang Aua. Dinamisia : Jurnal Pengabdian Kepada Masyarakat,2(2), 301-309. https://doi.org/10.31849/dinamisia.v2i2.1612.

Maarif, Vadlya, dkk. 2018. Aplikasi Pembelajaran Ilmu Tajwid Berbasis Android. Jurnal Evolusi Volume 6 No 1.91-100.

Maharani, S. ., \& Izzati, I. 2020. Pembelajaran Baca Tulis Al-Qur'an Anak Usia Dini .Jurnal Pendidikan Tambusai, 4(2), 1288-1298. https://doi.org/10.31004/jptam.v4i2.596.

Manna' al-Qaththan. (1998). Mabahits fi Ulumil Qur'an, Jakarta: Ummul Qura.

MUHAMMAD, Defy Habibi. 2018. Upaya Peningkatan Baca Tulis Al-Quran Melalui Metode Qiroati. JIE (Journal of Islamic Education), [S.I.], v. 3, n. 2, p. 142-162, jan. 2019. ISSN 
2528-0465.

Available

at:

<https://ejournal.stitmuhbangil.ac.id/index.php/jie/article/view/97>. Date accessed: 21 oct. 2021. doi: https://doi.org/10.29062/jie.v3i2.97.

Mulia, Hadi, dkk. 2017. Aplikasi Media Pembelajaran Ilmu Tajwid Dalam Mengucapkan Makharijul Huruf Hijaiyah. Jurnal Kepemimpinan Dan Pengurusan Sekolah Vol.2 No. 1 Th. 2017 (Page 1-6). e-ISSN: 2502-6445. P-ISSN: 2502-6437.

Musbah J. Aqel, Nida M. Zaitoun. 2015. Tajweed: An Expert System for Holy Qur'an Recitation Proficiency. International Conference on Communication, Management and Information Technology (ICCMIT 2015). Procedia Computer Science 65 ( 2015 ) 807 - 812.

Mustiawani, Vika. 2018. Kepotajwid: Aflikasi Pembelajaran Ilmu Tajwid Berbasis Web Interaktif. Indoesian Journal of Applied Informatics (IJAI). Vol. 2 No.2 pISSN; 2548-3846. eISSN: 25985981.

Nurhasan. Dkk. 2011. Buku Ajar Mata Kuliah Pengembangan Kepribadian Agama Islam. Palembang. Universitas Sriwijaya.

Ri'fat Syauqi Nawawi. (2011). Kepribadian Qur-ani, Jakarta: Amzah.

Rosniati Hakim, (2014). Jurnal Pendidikan Karakter, Tahun IV, Nomor 2.

Saprina, Sri. M.Irfan. 2020. Ability To Read Quran And Understanding Of Tajwid For Sriwijaya University Students. CONCIENCIA: Journal Islamic Education . vol. 20 No. 2 Desember 2020, $77-84$ p-ISSN: $1412-2545$ e-ISSN:

$2622-7304$

http://jurnal.radenfatah.ac.id/index.php/conciencia.

Sarikin, 2012. Jurnal Ilmu Tarbiyah, "At-Tajdid", Vol. 1, No. 1.

Sudiarjo, A., Mariana, A. R., \& Nurhidayat, W. (2015). Aplikasi Pembelajaran Ilmu Tajwid , Waqaf dan Makharijul Huruf Berbasis Android. Jurnal Sisfotek Global, 5(2), 54-60. Retrieved from http://journal.stmikglobal.ac.id/index.php/sisfotek/article/view/80.

Syekh Muhammad Ali Ash-Shabuni. (2001). Al-Tibyan fi Ulumil Qur'an, Jakarta: Pustaka

\section{Lampiran I}

\section{MATERI YANG DIBERIKAN}
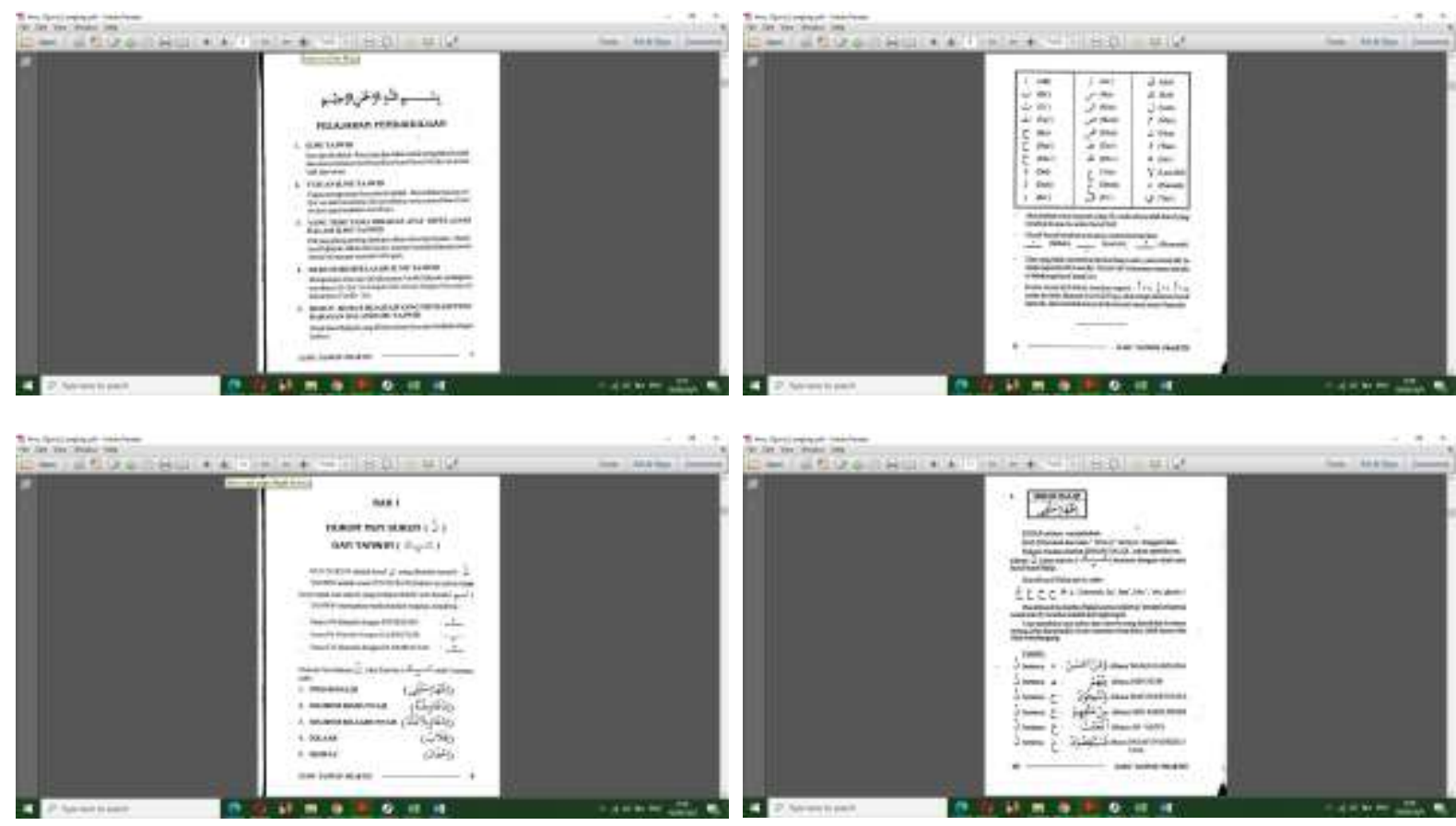

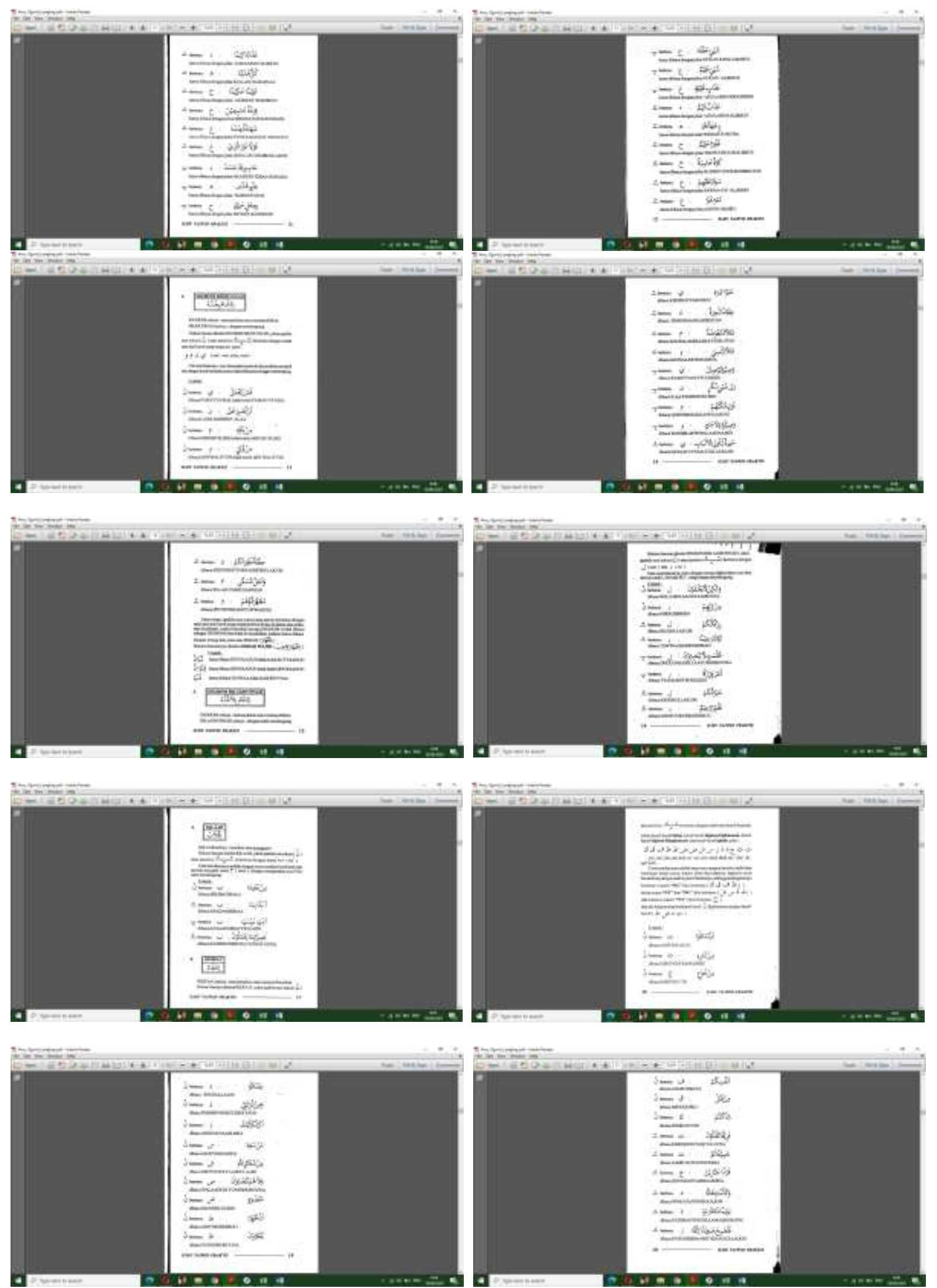


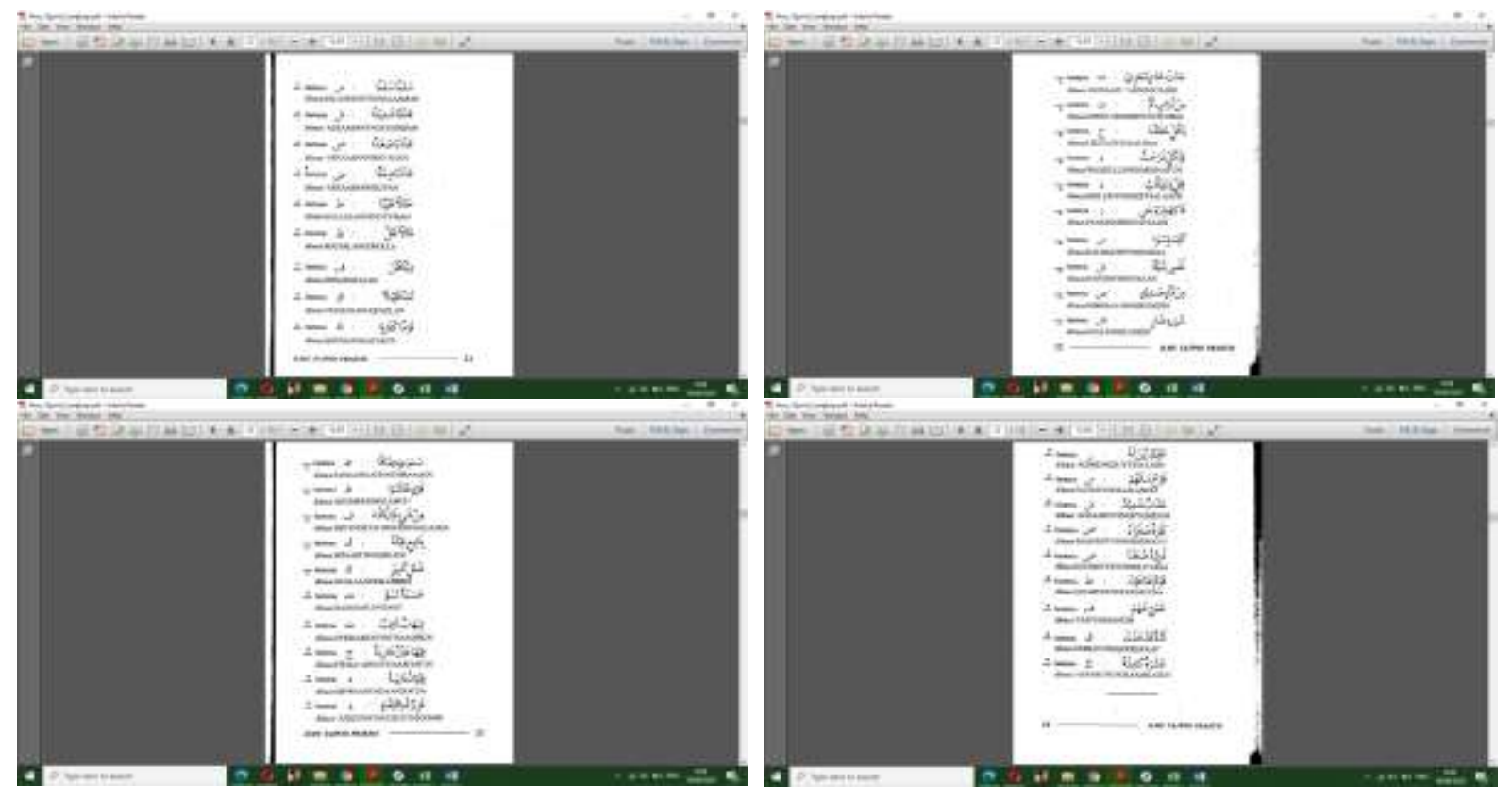




\section{Halaman Ini Dikosongkan}

